\title{
OPINI MASYARAKAT MENGENAI KEBUTUHAN SARANA TRANSPORTASI PUBLIK DI MUARA BUNGO PROVINSI JAMBI
}

\section{PUBLIC OPINION ABOUT THE NEEDS OF PUBLIC TRANSPORTATION IN MUARA BUNGO JAMBI PROVINCE}

\author{
Zepa Anggraini \\ STIA Setih Setio Muara Bunga Jambi \\ email: zevanggraini@yahoo.co.id
}

\begin{abstract}
Abstrak
Diskusi mengenai angkutan umum tidak terlepas dari definisi global public transport atau kegiatan pengangkutan yang melayani publik atau masyarakat umum. Terlihat bahwa angkutan umum muncul karena efek kongesti lalu lintas, sehingga muncul lima penyakit transportasi, yakni kemacetan, kesemrawutan, polusi (udara dan kebisingan), kecelakaan dan biaya tinggi. Sistem transportasi publik yang efektif di beberapa negara maju didukung keterlibatan subsidi pemerintah yang sangat besar. Penelitian ini bertujuan guna mengetahui Tingkat Keinginan Masyarakat terhadap ketersediaan sarana transportasi publik di Muara Bungo. Tipe penelitian yang digunakan adalah penelitian Deskriptif kuantitatif. Analisis ini menggunakan pengolahan data dalam bentuk angka (scoring) dan menggunakan analisis statistik menggunakan software spss 16. Tingkat Keinginan Masyarakat terhadap ketersediaan sarana transportasi publik di Muara Bungo, berdasarkan temuan dari 300 orang sampel, $97 \%$ responden memiliki opini mendukung penerapan Sistem Transportasi publik di wilayah Muara Bungo. Bentuk preferensi (pilihan) moda transportasi publik Moda masyarakat Muara Bungo, dari temuan penelitian menunjukkan pilihan responden jenis kendaraan yang cocok untuk transportasi publik adalah Bis Menengah sebesar $43 \%$. Secara teoritis, penelitian jenis ini bisa dipakai sebagai kajian awal/rintisan dalam pengembangan kebijakan publik. Bagi Pemerintah Daerah Kabupaten Bungo, perlu melakukan studi kelayakan sistem transportasi publik, mengacu pada temuan penelitian yang menunjukkan animo responden yang tinggi pada sarana transportasi publik.
\end{abstract}

Kata Kunci: Opini Masyarakat, Sarana Transportasi Publik, Muara Bungo.

\begin{abstract}
Discussions about public transportation are inseparable from the global definition of public transport or transportation activities that serve the public or the general public. It appears that public transportation arises because of traffic congestion effects, so that five transportation diseases arise, namely congestion, chaos, pollution (air and noise), accidents and high costs. Effective public transportation systems in some developed countries are supported by the involvement of enormous government subsidies. This study aims to determine the level of public interest in the availability of public transportation facilities in Muara Bungo. The type of research used is descriptive quantitative research. This analysis uses data processing in the form of scoring and uses statistical analysis using SPSS software. 16. The level of public interest in the availability of public transportation facilities in Muara Bungo, based on findings from 300 sample respondents, $97 \%$ of respondents
\end{abstract}


have a supporting opinion the implementation of the Public Transportation System in Muara Bungo area. The form of preference (choice) of the Muara Bungo Moda public transportation mode, from the research findings, shows that the choice of respondents in the type of vehicle suitable for public transportation is Intermediate Bus by $43 \%$. Theoretically, this type of research can be used as a preliminary study in developing public policy. For the Bungo District Government, it is necessary to conduct a study of the public transportation system feasilibily, referring to research findings that show the high interest of respondents on public transportation facilities.

Keywords: Public Opinion, Public Transportation Facilities, Muara Bungos

\section{PENDAHULUAN}

Pada perkembangannya transportasi publik bukan hanya menjadi masalah pemerintah, operator penyedia transportasi, melainkan juga masyarakat luas. Fenomena sosial di Indonesia yang terjadi saat ini mengedepankan wajah transportasi publik yang kurang memberikan kenyamanan, keamanan, dan keterjangkauan dan masih mengesankan biaya sosial dan ekonomi tinggi. Hal ini berakibat pada sulitnya masyarakat untuk melakukan mobilitasnya bergerak dari satu tempat ke tempat yang lain. Untuk daerah perkotaan, masalah transportasi yang terjadi adalah bagaimana memenuhi permintaan jumlah perjalanan yang semakin meningkat, tanpa menimbulkan kemacetan arus lalulintas di jalan raya. Masalahnya tidak hanya pada kemacetan lalulintas, tetapi juga pada perencanaan sistem transportasi. Ini memerlukan suatu penanganan yang menyeluruh. Kalau dilihat dari perkembangan transportasi perkotaan yang ada, terlepas dari krisis ekonomi, kendaraan pribadi (mobil dan sepeda motor) tetap merupakan moda transportasi yang dominan, baik untuk daerah urban (kota) maupun sub urban (pinggir kota).

Pada saat ini Kabupaten Bungo menjadi daerah yang berkembang secara ekonomi dan sosial budaya. Bungo menjadi kota terbesar kedua setelah kotamadya Jambi sebagai ibukota provinsi dalam hal kemajuan di segala bidang. Untuk bidang transportasi sendiri, terlihat perkembangan yang signifikan dalam hal kepemilikan kendaraan bermotor. Pada satu sisi, hal ini adalah bukti riil kesejahteraan masyarakat Bungo, pada sisi lain terdapat potensi-potensi hambatan sosial di masa depan bila tidak dicermati dengan baik melalui perencanaan yang matang sejak saat ini. Populasi pergerakan kendaraan pribadi yang begitu besar di daerah perkotaan ditambah dengan pola angkutan umum yang masih terbatas, menimbulkan biaya sosial yang sangat besar akibat waktu tempuh yang terbuang percuma, pemborosan bahan bakar minyak, depresi kendaraan yang terlalu cepat, kecelakaan lalu lintas, meningkatnya polusi udara, dan kebisingan. 
Permasalahan sentral yang tengah dihadapi Kabupaten Bungo saat ini adalah masih minimnya ketersediaan sarana transportasi publik. Sementara keinginan masyarakat akan kebutuhan sarana trasnportasi publik meningkat. Pada saat ini untuk menjalankan rutinitas baik itu berangkat ke tempat kerja, ke kantor, ngantar anak ke sekolah, ke tenpat wisata, ataupun pergi ke pusat pembelanjaan semuanya masih menggunakan kendaraan pribadi, akan tetapi sebagian orang yang belum memiliki kendaraan pribadi, mereka memilih sarana trasnsportasi umum. Berbagai macam sarana transportasi umum dimulai dari ojek motor, bajaj, mobil angkot, bus hingga kereta telah menjadi andalan bagi sebagian orang. Kebutuhan trasnsportasi publik di Kabupaten Bungo saat ini hanya dilayani oleh ojek motor.

Di Kabupaten Bungo kendaraan bermotor roda empat khususnya kendaraan pribadi dan sepeda motor pada saat ini semakin menjamur dan terus bertambah tanpa terkendali sehingga diperkirakan jika pemerintah daerah Kabupaten Bungo tidak melakukan tindakan maka pada masa yang akan datang, akan terjadi titik jenuh di mana jalan-jalan akan dipenuhi kendaraan bermotor, sehingga timbul permasalahan baru seperti kemacetan, polusi udara, akses akan menjadi terhambat, dan masih banyak permasalahan lain yang akan timbul, maka dari itu perlu kajian opini masyarakat mengenai kebutuhan trasnportasi publik. Kualitas infrastruktur jalan saat ini dalam keadaan baik, adapun panjang Kabupaten Bungo menurut Kecamatan dan jenis permukaan $(\mathrm{km})$ tahun 2016 adalah sebagai berikut: Aspal, 594.46 km, Kerikil, 150,26 km, dan Tanah $57.47 \mathrm{~km}$.

Adapun banyaknya kendaraan bermotor menurut jenisnya dari tahun ke tahun mengalami peningkatan, hal tersebut bisa terlihat pada tabel di bawah ini, ini adalah data dari tahun 2015 sampai tahun 2016.

\section{Tabel 1. Banyaknya Kendaraan Bermotor Menurut Jenisnya di Kabupaten Bungo, 2015}

\begin{tabular}{|l|c|c|c|}
\hline $\begin{array}{c}\text { Jenis } \\
\text { Kendaraan }\end{array}$ & Pemerintah & Swasta & Jumlah \\
\hline $\begin{array}{l}\text { Mobil } \\
\text { Penumpang }\end{array}$ & $\mathbf{1 4 3}$ & $\mathbf{7 2 8 2}$ & $\mathbf{7 4 2 5}$ \\
\hline Mobil Beban & $\mathbf{5 3}$ & $\mathbf{3 9 4 2}$ & $\mathbf{3 9 9 5}$ \\
\hline Bus & $\mathbf{7}$ & $\mathbf{5 9}$ & $\mathbf{6 6}$ \\
\hline Sepeda Motor & $\mathbf{6 3 1}$ & $\mathbf{2 2 5 0 0}$ & $\mathbf{2 3 1 3 1}$ \\
\hline \multicolumn{1}{|c|}{ Jumlah } & $\mathbf{8 3 4}$ & $\mathbf{3 3 7 8 3}$ & $\mathbf{3 4 6 1 7}$ \\
\hline
\end{tabular}

Sumber: Satuan Lalu Lintas Kepolisian Resort Bungo

Tabel 2. Banyaknya Kendaraan Bermotor Menurut Jenisnya di Kabupaten Bungo, 2016

\begin{tabular}{|l|c|c|c|}
\hline $\begin{array}{c}\text { Jenis } \\
\text { Kendaraan }\end{array}$ & Pemerintah & Swasta & Jumlah \\
\hline $\begin{array}{l}\text { Mobil } \\
\text { Penumpang }\end{array}$ & $\mathbf{1 8 6}$ & $\mathbf{7 9 0 9}$ & $\mathbf{8 0 9 5}$ \\
\hline Mobil Beban & $\mathbf{5 9}$ & $\mathbf{3 7 6 0}$ & $\mathbf{3 8 1 9}$ \\
\hline Bus & $\mathbf{9}$ & $\mathbf{4 5}$ & $\mathbf{5 4}$ \\
\hline Sepeda Motor & $\mathbf{7 1 2}$ & $\mathbf{2 9 9 0 1}$ & $\mathbf{3 0 6 1 3}$ \\
\hline \multicolumn{1}{|c|}{ Jumlah } & $\mathbf{9 6 6}$ & $\mathbf{4 1 6 1 5}$ & $\mathbf{4 2 ~ 5 8 1}$ \\
\hline
\end{tabular}

Sumber: Satuan Lalu Lintas Kepolisian Resort Bungo 
Dalam Undang-Undang Nomor 22 Tahun 2009 tentang Lalu Lintas dan Angkutan Jalan, pasal 138 disebutkan bahwa Pemerintah bertanggung jawab atas penyelenggaraan Angkutan Umum yang Selamat, Aman, Nyaman dan Terjangkau. Untuk melaksanakan tugas ini serta merealisasikannya tentu saja bukan hal yang mudah. Banyak tantangan yang harus dihadapi oleh pemerintah dalam hal ini Pemerintah Daerah Kabupaten Bungo. Berkaitan dengan perkembangan transportasi yang semakin meningkat di Kabupaten Bungo, maka potensi masalah yang muncul diantaranya:

1. Kendaraan bermotor roda empat khususnya kendaraan pribadi dan sepeda motor terus bertambah tanpa terkendali sehingga diperkirakan jika pemerintah daerah Kabupaten Bungo tidak melakukan tindakan maka pada masa yang akan datang, akan terjadi titik jenuh di mana jalan-jalan akan dipenuhi kendaraan bermotor.

2. Peningkatan pembangunan sarana jalan baru mengakibatkan tuntutan kendaraan yang melewatinya dalam jumlah yang lebih besar, di Muara Bungo memiliki luas wilayah administratif yang cukup besar untuk menjangkau seluruh sudut kawasan kota maka diperlukan sarana dan prasarana transportasi yang memadai.
3. Konsumsi Bahan Bakar Minyak (BBM) akan meningkat.

4. Semakin meningkatnya Angka Kecelakaan setiap waktunya.

5. Waktu tempuh dan biaya kurang efisien.

6. Kurang nyamannya dalam perjalanan.

7. Maraknya kendaraan pribadi yang dapat digunakan menjadi kendaraan penumpang umum atau tidak adanya izin trayek bagi angkutan umum yang ilegal.

Pada kenyataan tersebut, maka dapat diasumsikan kebijakan pemerintah Kabupaten Bungo adalah salah satu faktor penting dalam perkembangan transportasi di kabupaten Bungo. Oleh karena itu, maka perlu kiranya dilakukan suatu penelitian survei yang bertujuan untuk mengetahui keinginan masyarakat terhadap ketersediaan sarana transportasi publik di Muara Bungo.

\section{METODE PENELITIAN}

Metode penelitian yang digunakan adalah penelitian Deskriptif Kuantitatif. Analisis ini menggunakan pemahaman kuantitatif yang mana pengolahan data ini dalam bentuk angka (scoring) dan menggunakan analisis statistik, atau dapat juga disebut sebagai data kualitatif yang diangkakan (Sugiyono,2010). Pengumpulan data melalui kuesioner dilakukan langsung di lapangan. Penelitian deskriptif ini bertujuan untuk mengetahui seberapa besar keinginan 
masyarakat akan jenis kendaraan umum. Berdasarkan jenis penelitian di atas yaitu penelitian deskriptif yang dilaksanakan melalui pengumpulan data di lapangan, maka metode penelitian yang digunakan adalah metode survei jajak pendapat.

Dalam penelitian ini yang menjadi populasi adalah seluruh warga yang beraktivitas di wilayah kota Muara Bungo dan disepanjang jalur lintas sumatera mulai dari kawasan gerbang kompleks perkantoran kabupaten Bungo sampai dengan daerah jembatan batang bungo, dan jumlah populasinya tidak terhingga. Populasi tak terhingga bilamana anggota populasinya tidak dapat diperkirakan atau tidak dapat diketahui jumlahnya, dengan kata lain, batas-batasnya tidak dapat ditentukan secara kuantitatif.

Adapun yang menjadi populasi sasarannya adalah masyarakat yang bekerja, Pegawai Negeri Sipil, karyawan swasta, mahasiswa, pelajar, SLTA sederajat, dan ibuibu raumah tangga yang beraktivitas disekitar lokasi penelitian. Yang mana terdiri dari Kelurahan Pasir Putih, Kelurahan Sungai Kerjan, dan Kelurahan Batang Bungo.

Sampel yang digunakan dalam penelitian ini adalah dengan metode non probability sampling, karena populasi yang diteliti infinite, selain itu juga dilakukan pengambilan sampel secara Accidental Sampling yaitu teknik penentuan sampel berdasarkan kebetulan. Untuk menentukan jumlah sampel terhadap keinginan masyarakat terhadap kebutuhan sarana transportasi publik di Muara Bungo, maka penulis berpedoman kepada ketentuan yang dikemukakan oleh Sugiyono yang mana sampel yang diambil dari populasi berstrata dengan kesalahan $5 \%$ tingkat kepercayaan / presisi $95 \%$, dan ukuran sampel yang layak dalam penelitian adalah berjumlah 300 sampel.

Teknik pengumpulan data yang peneliti gunakan dalam penelitian ini adalah:

1. Studi Pustaka (Library Research)

2. Studi Lapangan (Field Research)

a. Kuesioner (Angket)

Yaitu berupa pengumpulan data yang dilakukan dengan cara memberikan beberapa pertanyaan atau pernyataan tertulis yang kemudian dikirim kepada responden untuk diisi.

b. Observasi

Yaitu metode pengumpulan data yang digunakan untuk menghimpun data penelitian dan data tersebut dihimpun dengan cara penggunaan panca indera.

Tahapan yang dilakukan dalam pengolahan data adalah sebagai berikut :

\section{Editing}

Merupakan kegiatan pemeriksaan terhadap data yang masuk apa terdapat kekeliruan dalam pengisian/kurang lengkap, tidak sesuai dan sebagainya. Editing dilakukan 
dengan harapan akan diperoleh data yang benar-benar valid, reliable, serta dapat dipertanggungjawabkan.

\section{Coding}

Merupakan proses pemberian tanda, simbol, ataupun kode setiap data yang termasuk dalam kelompok yang sama tanda tersebut dapat berupa angka atau huruf.

\section{Tabulating}

Merupakan tahap memasukan data pada tabel-tabel tertentu dan mengatur angkaangka serta memperhitungkannya.

Analisis data dilakukan setiap saat pengumpulan data secara berkesinambungan dan diawali dengan pengukuran yakni pemberian angka pada obyek-obyek atau kejadian-kejadian. Dalam pengukuran perlu diperhatikan bahwa terdapat kesamaan yang dekat antara realitas sosial yang diteliti dengan nilai yang diperoleh dari pengukuran. Pengukuran dalam penelitian ini merupakan pemberian angka-angka secara nominal terhadap berbagai indikator atau parameter dari seluruh variabel penelitian.

Analisa yang digunakan untuk menggunakan statistik deskriptif tentang kebutuhan masyarakat pada transportasi publik, yaitu dengan menggunakan instrumen SPSS series 16. Analisis data pada penelitian ini menggunakan analisis frekuensi, yaitu merupakan analisis yang mencakup gambaran frekuensi data secara umum seperti mean, media, modus, deviasi, standar, varian, minimum, maksimum dan sebagainya.

\section{HASIL PENELITIAN}

Data dikumpulkan dari bulan April sampai dengan Juni 2018. Pada saat pengambilan data partisipan yang mengisi angket berjumlah 300 orang dari jumlah sampel yang ada. Dari masyarakat yang mengisi 206 diantaranya berjenis laki-laki dan sisanya 94 perempuan. Sebaran umurnya antara $<20$ tahun sampai dengan $>40$ tahun, dan sebagian besar berasal dari Kota Muara Bungo dan sekitarnya.

Angket yang digunakan berisi 16 pertanyaan, yang meliputi pertanyaan mengenai:

1. Pertanyaan mengenai identitas responden (jenis kelamin, umur, pendidikan terakhir, pekerjaan, pendapatan/bulan, pengeluaran /bulan, dan pengeluaran untuk biaya transportasi/bulan)

2. Pertanyaan $1-4$ untuk menggali pengetahuan responden mengenai sistem transportasi publik massal

3. Pertanyaan $5-7$ untuk menggali sikap responden mengenai pelaksanaan sistem transportasi publik massal

4. Pertanyaan $8-16$ untuk menggali perilaku responden jika pemerintah menerapkan sistem transportasi publik massal 
Dari hasil perhitungan secara kuantitatif didapatkan gambaran sebagai berikut:

Tabel 3. Identitas Responden berdasarkan Jenis kelamin

\begin{tabular}{|c|c|c|c|c|}
\hline & $\begin{array}{c}\text { Freque } \\
\text { ncy }\end{array}$ & Percent & $\begin{array}{c}\text { Valid } \\
\text { Percen } \\
\mathrm{t}\end{array}$ & $\begin{array}{c}\text { Cum } \\
\text { ulati } \\
\text { e } \\
\text { Perc } \\
\text { nt }\end{array}$ \\
\hline Valid Laki-Lak & 205 & 68.3 & 68.3 & 68.3 \\
\hline Perempuan & 95 & 31.7 & 31.7 & 100. \\
\hline Total & 300 & 100.0 & 100.0 & \\
\hline
\end{tabular}

Berdasarkan tabel jenis kelamin diatas dapat terlihat bahwa dari jumlah 300 responden, terdiri dari 205 orang laki-laki yang mana jumlah persentasinya $68,33 \%$ dan 95 orang perempuan yang persentasinya $31.67 \%$.

Tabel 4. Identitas Responden berdasarkan Umur

\begin{tabular}{|c|c|c|c|c|}
\hline & $\begin{array}{c}\text { Frequenc } \\
\mathrm{y}\end{array}$ & $\begin{array}{c}\text { Perce } \\
\mathrm{nt}\end{array}$ & $\begin{array}{c}\text { Valid } \\
\text { Percent }\end{array}$ & $\begin{array}{c}\text { Cumula } \\
\text { tive } \\
\text { Percent }\end{array}$ \\
\hline $\begin{array}{c}\text { Valid }<20 \text { th } \\
>40 \text { th } \\
21-30 \\
\text { th }\end{array}$ & 38 & 7.3 & 7.3 & 7.3 \\
& 166 & 55.3 & 55.3 & 75.3 \\
$\begin{array}{l}31-40 \\
\text { th } \\
\text { Total }\end{array}$ & 74 & 24.7 & 24.7 & 100.0 \\
\hline
\end{tabular}

Tabel di atas berdasarkan umur, dapat terlihat paling dominan dari responden yaitu sekitar umur 21 - 30 tahun, sedangkan yang paling kecil persentasinya yaitu umur $<20$ tahun yang respondennya hanya 22 orang.
Tabel 5. Identitas Responden berdasarkan Pendidikan Terakhir

\begin{tabular}{|c|c|c|c|c|}
\hline & $\begin{array}{c}\text { Frequ } \\
\text { ency }\end{array}$ & $\begin{array}{c}\text { Perce } \\
\text { nt }\end{array}$ & $\begin{array}{c}\text { Valid } \\
\text { Percent }\end{array}$ & $\begin{array}{c}\text { Cumulati } \\
\text { ve } \\
\text { Percent }\end{array}$ \\
\hline Valid Akademi & 25 & 8.3 & 8.3 & 8.3 \\
P.Tinggi & 81 & 27.0 & 27.0 & 35.3 \\
SD & 3 & 1.0 & 1.0 & 36.3 \\
SLTA & 172 & 57.3 & 57.3 & 93.7 \\
SLTP & 19 & 6.3 & 6.3 & 100.0 \\
Total & 300 & 100.0 & 100.0 & \\
\hline
\end{tabular}

Berdasarkan tabel kuesioner di atas dapat ditarik kesimpulan bahwa kebanyakan responden yang pendidikan terakhirnya adalah SLTA yang mendapatkan persentasi sebanyak $57,33 \%$ yang terdiri dari 172 orang.

Tabel 6. Identitas Responden berdasarkan Pekerjaan

\begin{tabular}{|c|c|c|c|c|}
\hline & $\begin{array}{c}\text { Freque } \\
\text { ncy }\end{array}$ & $\begin{array}{c}\text { Perce } \\
\text { nt }\end{array}$ & $\begin{array}{c}\text { Valid } \\
\text { Percent }\end{array}$ & $\begin{array}{c}\text { Cumulative } \\
\text { Percent }\end{array}$ \\
\hline $\begin{array}{l}\text { Vali Mahasi } \\
\text { d sw }\end{array}$ & 36 & 12.0 & 12.0 & 12.0 \\
PNS & 76 & 25.3 & 25.3 & 37.3 \\
Siswa & 9 & 3.0 & 3.0 & 40.3 \\
Swasta & 179 & 59.7 & 59.7 & 100.0 \\
& & 100.0 & 100.0 & \\
Total & 300 & & & \\
\hline
\end{tabular}

Tabel di atas dapat ditari kesimpulan bahwa karyawan swasta mendapatkan persentasi paling besar yaitu $59,67 \%$ yang respondennya terdiri dari 179 orang. 
Tabel 7. Identitas Responden berdasarkan Pendapatan/bulan

\begin{tabular}{|c|c|c|c|c|}
\hline & Freque & Perce \\
ncy & nt & $\begin{array}{c}\text { Valid } \\
\text { Percent }\end{array}$ & $\begin{array}{c}\text { Cumu } \\
\text { lative } \\
\text { Perce } \\
\text { nt }\end{array}$ \\
\hline Valid <500000 & 12 & 4.0 & 4.0 & 4.0 \\
$>2000000$ & 128 & 42.7 & 42.7 & 46.7 \\
1000000 & 39 & 13.0 & 13.0 & 59.7 \\
1500000 & 90 & 30.0 & 30.0 & 89.7 \\
500000 & 31 & 10.3 & 10.3 & 100.0 \\
Total & 300 & 100.0 & 100.0 & \\
\hline
\end{tabular}

Dari data diatas, dapat kita lihat hasil perolehan responden yang pendapatan / bulannya mendapatkan persentasi terbesar adalah responden yang pendapatannya sebesar $1.500 .000,00-2.000 .000,00$ yaitu nilai persentasinya $30 \%$ dari jumlah responden.

Tabel 8. Identitas Responden berdasarkan Pengeluaran/bulan

\begin{tabular}{|c|c|c|c|c|}
\hline & $\begin{array}{c}\text { Frequ } \\
\text { ency }\end{array}$ & $\begin{array}{c}\text { Perce } \\
\text { nt }\end{array}$ & $\begin{array}{c}\text { Valid } \\
\text { Percent }\end{array}$ & $\begin{array}{c}\text { Cumulati } \\
\text { ve } \\
\text { Percent }\end{array}$ \\
\hline Valid <500000 & 40 & 13.3 & 13.3 & 13.3 \\
$>2000000$ & 42 & 14.0 & 14.0 & 27.3 \\
1000000 & 47 & 15.7 & 15.7 & 43.0 \\
1500000 & 54 & 18.0 & 18.0 & 61.0 \\
500000 & 117 & 39.0 & 39.0 & 100.0 \\
Total & 300 & 100.0 & 100.0 & \\
\hline
\end{tabular}

Tabel di atas menunjukkan bahwa identitas responden berdasarkan pengeluaran / bulan yang persentasinya tertinggi adalah $39 \%$ yang mana rata-rata pengeluaran sejumlah $\mathrm{Rp}$ $500.000,00-R p 1.000 .000,00$ yang jumlah respondennya sebanyak 117 orang dari jumlah sampel.

Tabel 9. Identitas berdasarkan

Pengeluaran untuk biaya transportasi/bulan

\begin{tabular}{|c|c|c|c|c|}
\hline & Frequency & Percent & $\begin{array}{c}\text { Valid } \\
\text { Percent }\end{array}$ & $\begin{array}{c}\text { Cumulativ } \\
\text { e Percent }\end{array}$ \\
\hline Valid & $<100000$ & 86 & 28.7 & 28.7 \\
& $>1000000$ & 12 & 4.0 & 4.0 \\
100000 & 167 & 55.7 & 55.7 \\
& 500000 & 35 & 11.7 & 11.7 \\
& Total & 300 & 100.0 & 100.0 \\
\hline
\end{tabular}

Tabel di atas menunjukkan bahwa identitas responden berdasarkan pengeluaran / bulan untuk biaya transportasi yang persentasinya tertinggi adalah $55,67 \%$ yang mana rata-rata pengeluaran sejumlah $\mathrm{Rp}$ $100.000,00$ - Rp 500.000,00 yang jumlah respondennya sebanyak 167 orang dari jumlah sampel.

Tabel 10. Pengetahuan tentang Transportasi Publik (STP)

\begin{tabular}{|c|c|c|c|c|c|}
\hline & & $\begin{array}{c}\text { Frequen } \\
\text { cy }\end{array}$ & $\begin{array}{c}\text { Percen } \\
\mathrm{t}\end{array}$ & $\begin{array}{c}\text { Valid } \\
\text { Percent }\end{array}$ & $\begin{array}{l}\text { Cumulativ } \\
\text { e Percent }\end{array}$ \\
\hline \multirow[t]{3}{*}{ Valid } & T. Tahu & 28 & 9.3 & 9.3 & 9.3 \\
\hline & Tahu & 272 & 90.7 & 90.7 & 100.0 \\
\hline & Total & 300 & 100.0 & 100.0 & \\
\hline
\end{tabular}

peneliti, dapat di lihat pada tabel di atas bahwa pengetahuan responden akan sistem transportasi publik ternyata yang tahu dan tidak tahu sangat jauh berbeda, jumlah persentasinya pada responden yang tahu akan 
Sistem Transportasi Publik adalah 90,67\% sedangkan yang tidak tahu hanya 9,33\% .

\section{Tabel 11. Sumber informasi tentang Sistem} Transportasi Publik

\begin{tabular}{|c|c|c|c|c|c|}
\hline & & $\begin{array}{c}\text { Frequen } \\
\text { cy }\end{array}$ & $\begin{array}{c}\text { Percen } \\
\mathrm{t}\end{array}$ & $\begin{array}{c}\text { Valid } \\
\text { Percent }\end{array}$ & $\begin{array}{c}\text { Cumulat } \\
\text { ive } \\
\text { Percent }\end{array}$ \\
\hline \multirow[t]{4}{*}{ Valid } & M.S. Online & 30 & 10.0 & 10.0 & 10.0 \\
\hline & Media Massa & 221 & 73.7 & 73.7 & 83.7 \\
\hline & Orang lain & 49 & 16.3 & 16.3 & 100.0 \\
\hline & Total & 300 & 100.0 & 100.0 & \\
\hline
\end{tabular}

Tabel di atas dapat dilihat dari jumlah responden yang telah di survei, kebanyakan rerponden mengetahui informasi tentang Sistem Transportasi Publik Massal yaitu dari media massa konvensional (TV, Koran, Majalah, Radio, Spanduk, Brosur) yang mana jumlah persentasinya sebanyak $73,67 \%$ dengan jumlah responden 221 orang.

Tabel 12. Sumber Informasi yang diharapkan tentang Sistem Transportasi Publik

\begin{tabular}{|cc|c|c|c|c|}
\hline & $\begin{array}{c}\text { Frequen } \\
\mathrm{cy}\end{array}$ & $\begin{array}{c}\text { Percen } \\
\mathrm{t}\end{array}$ & $\begin{array}{c}\text { Valid } \\
\text { Percent }\end{array}$ & $\begin{array}{c}\text { Cumulativ } \\
\text { e Percent }\end{array}$ \\
\hline Valid & Brosr & 36 & 12.0 & 12.0 & 12.0 \\
& Koran & 57 & 19.0 & 19.0 & 31.0 \\
& M.sos & 1 & .3 & .3 & 31.3 \\
Majal & 8 & 2.7 & 2.7 & 34.0 \\
Radio & 7 & 2.3 & 2.3 & 36.3 \\
TV & 174 & 58.0 & 58.0 & 94.3 \\
Web & 17 & 5.7 & 5.7 & 100.0 \\
Total & 300 & 100.0 & 100.0 & \\
\hline
\end{tabular}

Berdasarkan tabel di atas, responden perlu mengetahui lebih jauh tentang Sistem Transportasi Publik, responden mengharapkan informasi dari televisi yang mana jumlah persentasinya yaitu 58\% dari jumlah sampel.

Tabel 13. Persepsi mengenai peran pemerintah dalam memberi informasi mengenai Sistem Transportasi Publik

\begin{tabular}{|c|c|c|c|c|}
\hline & Frequency & Percent & $\begin{array}{r}\text { Valid } \\
\text { Percent }\end{array}$ & $\begin{array}{c}\text { Cumulative } \\
\text { Percent }\end{array}$ \\
\hline $\begin{array}{c}\text { Valid Kurang } \\
\text { Memadai } \\
\text { Sangat } \\
\text { Memadai }\end{array}$ & 57 & 19.0 & 19.0 & 93.0 \\
Tidak & 21 & 7.0 & 7.0 & 100.0 \\
sama sek & 300 & 100.0 & 100.0 & \\
Total & & & \\
\hline
\end{tabular}

Dapat kita lihat dari data tabel diatas, bahwa menurut responden peran pemerintah dalam memberikan informasi mengenai Sistem Transportasi Publik kurang memadai sehingga didapatkan jumlah persentasinya sebanyak $74 \%$.

Tabel 14. Sikap terhadap pelaksanaan Sistem Transportasi Publik

\begin{tabular}{|r|c|c|c|c|}
\hline & Frequency & $\begin{array}{c}\text { Percen } \\
\mathrm{t}\end{array}$ & $\begin{array}{c}\text { Valid } \\
\text { Percent }\end{array}$ & $\begin{array}{c}\text { Cumulative } \\
\text { Percent }\end{array}$ \\
\hline Valid Setuju & 291 & 97.0 & 97.0 & 97.0 \\
T. set & 9 & 3.0 & 3.0 & 100.0 \\
Total & 300 & 100.0 & 100.0 & \\
\hline
\end{tabular}

Dapat kita lihat dari data tabel diatas, bahwa responden yang setuju dan tidak setuju 
sangat jauh perbedaannya yaitu untuk yang setuju mendapatkan persentasi sebanyak $97 \%$, sedangkan yang tidak setuju hanya $3 \%$.

Tabel 15. Alasan setuju pelaksanaan Sistem Transportasi Publik

\begin{tabular}{|c|c|c|c|c|}
\hline & Frequency & Percent & $\begin{array}{c}\text { Valid } \\
\text { Percent }\end{array}$ & $\begin{array}{c}\text { Cumulative } \\
\text { Percent }\end{array}$ \\
\hline $\begin{array}{l}\text { Valid M. } \\
\text { kemacetan } \\
\text { lalu lintas } \\
\text { M. } \\
\text { pemakaian } \\
\text { kendaraan } \\
\text { pribad } \\
\text { M. resiko } \\
\text { kecelakaan } \\
\text { Menghemat } \\
\text { biaya } \\
\text { transportasi } \\
\text { Mengurangi } \\
\text { polusi } \\
\text { udara } \\
\text { Total }\end{array}$ & 300 & $\begin{array}{l}14.3 \\
22.7\end{array}$ & $\begin{array}{l}21.7 \\
14.3 \\
22.7\end{array}$ & $\begin{array}{l}51.7 \\
66.0 \\
88.7\end{array}$ \\
\hline
\end{tabular}

Dari tabel di atas tampak jelas, bahwa responden setuju dengan pelaksanaan Sistem Transportasi Publik, karena setiap responden memiliki pilihan alasan yang berbeda-beda, namun kebanyakan responden setuju dengan alasan dapat mengurangi kemacetan lalu lintas yang mana jumlah persentasinya yaitu $30 \%$ yang jumlah respondennya sebanyak 90 orang.
Tabel 16. Alasan tidak setuju pelaksanaan Sistem Transportasi Publik

\begin{tabular}{|l|c|c|c|c|}
\hline & Frequency & Percent & $\begin{array}{c}\text { Valid } \\
\text { Percent }\end{array}$ & $\begin{array}{c}\text { Cumulative } \\
\text { Percent }\end{array}$ \\
\hline $\begin{array}{l}\text { Valid Kurang } \\
\text { nyaman di } \\
\text { perjal }\end{array}$ & 74 & 24.7 & 24.7 & 24.7 \\
$\begin{array}{l}\text { Sarana jalan } \\
\text { memadai ba } \\
\text { Tidak praktis }\end{array}$ & 30 & 10.0 & 10.0 & 34.7 \\
$\begin{array}{l}\text { Tingkat } \\
\text { keamanan } \\
\text { rendah }\end{array}$ & 83 & 27.7 & 27.7 & 76.0 \\
$\begin{array}{l}\text { Waktu } \\
\text { tempuh lebih } \\
\text { lama }\end{array}$ & 72 & 24.0 & 24.0 & 100.0 \\
Total & 300 & 100.0 & 100.0 & \\
\hline
\end{tabular}

Berdasarkan tabel di atas, dapat kita lihat juga alasan responden tidak setuju dengan adanya pelaksanaan Sistem Transportasi Publik, karena tingkat keamanan rendah, yang mana jumlah persentasinya yaitu $27,67 \%$.

Tabel 17. Ketertarikan mencoba Bila Pemerintah menerapkan Sistem Transportasi Publik di Bungo

\begin{tabular}{|c|c|c|c|l|}
\hline & Frequency & Percent & $\begin{array}{l}\text { Valid } \\
\text { Percent }\end{array}$ & $\begin{array}{l}\text { Cumulative } \\
\text { Percent }\end{array}$ \\
\hline $\begin{array}{c}\text { Valid T. tertarik } \\
\text { menc }\end{array}$ & 25 & 8.3 & 8.3 & 8.3 \\
$\begin{array}{c}\text { Tertarik } \\
\text { mencoba }\end{array}$ & 275 & 91.7 & 91.7 & 100.0 \\
Total & 300 & 100.0 & 100.0 & \\
\hline
\end{tabular}

Dapat dilihat dari tabel di atas, apabila pemerintah menerapkan Sistem Transportasi Publik di Bungo, kebanyakan jumlah responden tertarik mencoba dengan jumlah persentasi $91,67 \%$ sedangkan yang tidak 
tertarik mencoba hanya $8,33 \%$ karena berbagai alasan.

\section{Tabel 18. Jenis kendaraan yang cocok untuk Sistem Transportasi Publik menurut responden}

\begin{tabular}{|c|c|c|c|c|c|}
\hline & & $\begin{array}{c}\text { Freque } \\
\text { ncy }\end{array}$ & $\begin{array}{c}\text { Perc } \\
\text { ent }\end{array}$ & $\begin{array}{l}\text { Valid } \\
\text { Percent }\end{array}$ & $\begin{array}{c}\text { Cumulative } \\
\text { Percent }\end{array}$ \\
\hline \multirow[t]{5}{*}{ Valid } & Angkutan kot & 86 & 28.7 & 28.7 & 28.7 \\
\hline & Bis besar & 54 & 18.0 & 18.0 & 46.7 \\
\hline & $\begin{array}{l}\text { Bis } \\
\text { menengah }\end{array}$ & 128 & 42.7 & 42.7 & 89.3 \\
\hline & Kereta wisat & 32 & 10.7 & 10.7 & 100.0 \\
\hline & Total & 300 & $\begin{array}{c}100 . \\
0\end{array}$ & 100.0 & \\
\hline
\end{tabular}
diperlihatkan jenis kendaraan yang cocok untuk Sistem Transportasi Publik menurut responden yang ada di kota Bungo ternyata lebih tertarik dengan jenis Bis Menengah dengan jumlah persentasinya sebesar $43 \%$ sedangkan jumlah terendah yaitu $10,67 \%$ memilih jenis kereta wisata (city train).

Tabel 19. Perlu/tidak dibangun stasiun pemberhentian utama / terminal pusat (central station)?

\begin{tabular}{|r|c|c|c|c|}
\hline & Frequency & Percent & $\begin{array}{c}\text { Valid } \\
\text { Percent }\end{array}$ & $\begin{array}{c}\text { Cumulative } \\
\text { Percent }\end{array}$ \\
\hline Valid Perlu & 281 & 93.7 & 93.7 & 93.7 \\
T.per & 19 & 6.3 & 6.3 & 100.0 \\
Total & 300 & 100.0 & 100.0 & \\
\hline
\end{tabular}

Dari tabel diatas, dapat dilihat pendapat responden mengenai perlunya dibangun stasiun pemberhentian utama / terminal pusat jika diterapkannya Sistem Transportasi Publik, sebanyak 281 orang yang jumlah persentasinya
93,67\% mengatakan perlu dibangun stasiun pemberhentian utama/terminal pusat, sedangkan 19 orang yang jumlah persentasinya $6,33 \%$ mengatakan tidak perlu.

Tabel 20. Perlu/tidak dibangun stasiun pemberhentian sementara / terminal transit (transitstation)?

\begin{tabular}{|r|c|c|c|c|}
\hline & $\begin{array}{c}\text { Frequenc } \\
\text { y }\end{array}$ & Percent & $\begin{array}{c}\text { Valid } \\
\text { Percent }\end{array}$ & $\begin{array}{c}\text { Cumulati } \\
\text { ve } \\
\text { Percent }\end{array}$ \\
\hline Valid Perlu & 262 & 87.3 & 87.3 & 87.3 \\
T.per & 38 & 12.7 & 12.7 & 100.0 \\
Total & 300 & 100.0 & 100.0 & \\
\hline
\end{tabular}

Dari tabel di atas, dapat dilihat pendapat responden mengenai perlunya dibangun stasiun pemberhenian sementara/ terminal transit jika diterapkannya Sistem Transportasi Publik, sebanyak 262 orang yang jumlah persentasinya $87,33 \%$ mengatakan perlu dibangun stasiun pemberhentian sementara / terminal transit, sedangkan 38 orang yang jumlah persentasinya $12,67 \%$ mengatakan tidak perlu.

Tabel 21. Perlu diterapkan jalur / trayek khusus?

\begin{tabular}{|c|c|c|c|c|c|}
\hline & & $\begin{array}{c}\text { Frequen } \\
\text { cy }\end{array}$ & Percent & $\begin{array}{l}\text { Valid } \\
\text { Percent }\end{array}$ & $\begin{array}{l}\text { Cumulativ } \\
\text { e Percent }\end{array}$ \\
\hline \multirow[t]{3}{*}{ Valid } & Perlu & 280 & 93.3 & 93.3 & 93.3 \\
\hline & T.per & 20 & 6.7 & 6.7 & 100.0 \\
\hline & Total & 300 & 100.0 & 100.0 & \\
\hline
\end{tabular}

Dari tabel di atas, dapat dilihat pendapat responden mengenai perlunya diterapkan jalur / trayek khusus jika diterapkannya Sistem 
Transportasi Publik, sebanyak 280 orang yang jumlah persentasinya $93,33 \%$ mengatakan perlu diterapkan jalur / trayek khusus, sedangkan 20 orang yang jumlah persentasinya $6,7 \%$ mengatakan tidak perlu.

Tabel 22. Harga tiket / biaya perjalanan untuk 1 kali jalan, menurut responden

\begin{tabular}{|c|c|c|c|c|c|}
\hline & & Frequency & $\begin{array}{c}\text { Percen } \\
t\end{array}$ & $\begin{array}{l}\text { Valid } \\
\text { Percent }\end{array}$ & $\begin{array}{c}\text { Cumulative } \\
\text { Percent }\end{array}$ \\
\hline & $<3000$ & 183 & 61.0 & 61.0 & 61.0 \\
\hline & $>5000$ & 17 & 5.7 & 5.7 & 66.7 \\
\hline & 3000 & 100 & 33.3 & 33.3 & 100.0 \\
\hline & Total & 300 & 100.0 & 100.0 & \\
\hline
\end{tabular}

Dari tabel diatas, dapat dilihat $61 \%$ respoden memilih harga tiket / biaya perjalanan untuk 1 kali jalan, yaitu $<$ Rp 3.000,00 sedangkan sangat sedikit responden yang memilih harga tiket / biaya perjalanan untuk 1 kali jalan > Rp 5.000,00 yaitu hanya 5,67\% dari jumlah responden.

Tabel 23. fasilitas yang sangat diperlukan dari Sarana Transportasi Publik

\begin{tabular}{|c|c|c|c|c|c|}
\hline & & $\begin{array}{c}\text { Frequen } \\
\text { cy }\end{array}$ & Percent & $\begin{array}{c}\text { Valid } \\
\%\end{array}$ & $\begin{array}{l}\text { Cumulativ } \\
\text { e Percent }\end{array}$ \\
\hline \multirow[t]{7}{*}{ Valid } & Kabin yang luas & 10 & 3.3 & 3.3 & 3.3 \\
\hline & $\begin{array}{l}\text { Kapasitas angkut } \\
\text { besar }\end{array}$ & 4 & 1.3 & 1.3 & 4.7 \\
\hline & $\mathrm{AC}$ & 45 & 15.0 & 15.0 & 19.7 \\
\hline & $\begin{array}{l}\text { Petugas } \\
\text { keamanan }\end{array}$ & 112 & 37.3 & 37.3 & 57.0 \\
\hline & $\begin{array}{l}\text { Sistem pem. yg } \\
\text { praktis }\end{array}$ & 29 & 9.7 & 9.7 & 66.7 \\
\hline & $\begin{array}{l}\text { Tempat duduk } \\
\text { nyaman }\end{array}$ & 100 & 33.3 & 33.3 & 100.0 \\
\hline & Total & 300 & 100.0 & 100.0 & \\
\hline
\end{tabular}

Tabel di atas menunjukkan jumlah persentasi tertinggi adalah $37,33 \%$ untuk jawaban Petugas keamanan dalam asfek fasilitas yang sangat diperlukan dari Sarana Transportasi Publik, sedangkan jumlah persentasi terendah adalah 1,33\% yang menjawab kapasitas angkut besar dalam asfek fasilitas yang sangat diperlukan dari Sarana Transportasi Publik.

\section{Tabel 24. Subsidi pemerintah / pemerintah daerah pada sektor transportasi}

\begin{tabular}{|c|c|c|c|c|}
\hline & Frequency & Percent & Valid & Cumulative \\
Percent & Percent \\
\hline Valid Kurang perlu & 19 & 6.3 & 6.3 & 6.3 \\
Sangat perlu & 279 & 93.0 & 93.0 & 99.3 \\
Tidak perlu & 2 & .7 & .7 & 100.0 \\
Total & 300 & 100.0 & 100.0 & \\
\hline
\end{tabular}

Berdasarkan data diatas bahwa sebanyak 279 orang yang mengatakan sangat perlu dengan subsidi pemerintah / pemerintah daerah pada sektor transportasi publik dan 19 orang yang mengatakan kurang perlu dan 2 orang yang mengatakan tidak perlu.

\section{Tabel 25. Pemerintah Daerah melakukan kajian / studi kelayakan}

\begin{tabular}{|c|c|c|c|c|}
\hline & $\begin{array}{c}\text { Frequen } \\
\text { cy }\end{array}$ & $\begin{array}{c}\text { Percen } \\
\mathrm{t}\end{array}$ & $\begin{array}{c}\text { Valid } \\
\text { Percent }\end{array}$ & $\begin{array}{c}\text { Cumulat } \\
\text { ive } \\
\text { Percent }\end{array}$ \\
\hline Valid $\begin{array}{l}\text { Kurang } \\
\text { perlu } \\
\text { Sangat } \\
\text { perlu } \\
\text { Tidak } \\
\text { perlu } \\
\text { Total }\end{array}$ & 9 & 3.0 & 3.0 & 3.0 \\
\hline
\end{tabular}


Berdasarkan tabel di atas, dapat dilihat hasil perolehan responden yang sangat perlu dengan pemerintah daerah melakukan kajian/studi kelayakan sebanyak 290 orang atau sebesar 96,67\% sedangkan untuk responden yang kurang perlu sebanyak 9 orang atau sebesar 3\% dan yang tidak perlu sebanyak 1 orang atau sebesar $0,33 \%$.

\section{PEMBAHASAN}

Penelitian ini sesuai dengan konsep yang dikembangkan oleh Siti Aminah dalam bentuk jurnal yang berjudul "Transportasi Publik dan Aksebilitas Perkotaan di Surabaya". Hasil penelitian menunjukkan bahwa: Karakter umum transportasi publik melayani masyarakat dengan mobilitas dan akses pada pekerjaan, sumber-sumber sosial ekonomi politik, pusat kesehatan, dan tempat rekreasi. Apapun motivasi masyarakat, baik yang sadar dan memutuskan untuk memilih transportasi umum ataupun yang terpaksa karena tidak memiliki pilihan lain, ada kecenderungan penumpang transportasi umum tidak memiliki mobil dan harus bergantung pada transportasi umum.

Bagi pemerintah penyelenggaraan transportasi publik berarti adanya pemerintah membuat kebijakan untuk pengadaan transportasi itu mulai dari yang bersifat teknis, sosiologis hingga politis, seperti pengadaan lahan, penataan ruang, modal, dan sebagainya.
Ini berlanjut pada interaksi pemerintah dengan kekuatan kapital. Untuk membangun sistem transportasi publik berkelanjutan perlu adanya revitalisasi dalam semua aspek yang berkaitan dengan transportasi publik. Pemerintah kota berperan penting dalam membuat perencanaan dan implementasi kebijakan transportasi publik.

Menurut Endar Wismulyani, Transportasi adalah pengangkutan barang atau manusia oleh berbagai jenis kendaraan sesuai dengan kemajuan teknologi. Transportasi sangat penting artinya bagi kita, dengan alat transportasi kita dapat menjangkau berbagai tempat yang ingin kita kunjungi dengan mudah dan dalam waktu yang relatif singkat pula, manfaat alat transportasi berhasil dinikmati dengan perkembangan zaman, setelah manusia mengembangkan berbagai penemuan baru dalam bidang transportasi beserta peralatan penunjangnya (Endar Wismulyani, 2008).

Menurut Ferguson Erik dalam bukunya yang berjudul Transportation Demand Management-Planning, Development, and Implementation, Manajemen sistem transportasi dilakukan dengan dua cara pendekatan, yaitu:

1. Manajemen Penyediaan Transportasi (Transportation Supply Management)

Penyediaan transportasi meliputi penyediaan sarana dan prasarana transportasi. Prasarana transportasi 
mencakup jalan umum, terminal, pelabuhan laut, rel kereta api, lapangan terbang yang semuanya membentuk suatu jaringan transportasi. Sedangkan sarana transportasi adalah menyangkut jenis kendaraan yang digunakan untuk transportasi (mode of transport).

2. Manajemen Permintaan Transportasi (Transportation Demand Management)

Masalah transportasi sudah menjadi isu kebijaksanaan publik karena dampaknya secara material, waktu, dan kenyamanan sudah cukup besar, biasanya, pemecahan masalah transportasi dilakukan dengan penyediaan (supply) sarana dan prasarana transportasi sesuai dengan peningkatan kebutuhan transportasi (Mulyono Sadyohutomo, 2008).

\section{Adapun Tingkat Keinginan Masyarakat terhadap ketersediaan sarana transportasi publik di Muara Bungo.}

a. Informasi Mengenai Sistem Transportasi Publik pada Responden Berdasarkan temuan dari 300 orang sampel, $97 \%$ hampir seluruh responden memiliki opini mendukung penerapan Sistem Transportasi di wilayah Kota Muara Bungo. Hal ini didasari semakin terbukanya informasi terhadap perubahan dan kemajuan dari kotakota yang lebih maju dalam pelaksanaan transportasi massal. Pada sisi lain, kenyataan terbukanya arus informasi mengenai transportasi publik yang didapat masyarakat dari media massa, berbanding terbalik dengan peran pemerintah dalam memberikan informasi mengenai Sistem Transportasi Publik, sebanyak $74 \%$ responden menyatakan informasi dari pemerintah kurang memadai. Mencermati lebih kajian teori, bahwa opini publik terbentuk dari integrasi "personal opinion" banyak orang. Lebih lanjut, dari 3 kategori pendekatan prinsip terhadap kajian opini publik, yakni :

1) Pengukuran kuantitatif terhadap distribusi opini.

2) Penelitian terhadap hubungan internal antara opini individu yang membentuk opini publik pada suatu permasalahan

3) Deskripsi tentang atau analisis terhadap peran publik dari opini publik.

Menunjukkan bahwa kajian opini publik dalam beberapa hal, diantaranya mengenai sistem transportasi publik yang penulis lakukan adalah untuk menunjukkan representasi pendapat masyarakat secara kuantitas, dan mendapat informasi mengenai gejala keinginan masyarakat yang membentuk suatu kategori opini umum. Hal ini pada gilirannya dapat menunjukkan gambaran peran opini publik terhadap perkembangan kemajuan suatu wilayah.

b. Perlunya Kajian Transportasi Publik di Muara Bungo 
Dye mengatakan bahwa, "Kebijakan

Publik adalah apa yang dipilih oleh pemerintah untuk dikerjakan atau tidak dikerjakan". Melalui definisi tersebut mendapat pemahaman bahwa terdapat perbedaan antara apa yang akan dikerjakan pemerintah dan apa yang sesungguhnya harus dikerjakan pemerintah (Leo Agustino, 2008). Istilah "Publik" dalam rangkaian kata publik policy mengandung tiga konotasi; pemerintah, masyarakat, dan umum. ini dapat dilihat dalam dimensi subjek, objek, dan lingkungan dari kebijakan. Dalam dimensi subjek, kebijakan publik adalah kebijakan dari pemerintah (Said zainal Abidin, 2006). Kebijakan dari pemerintahlah yang dapat dianggap kebijakan yang resmi dan dengan demikian mempunyai kewenangan yang dapat memaksa masyarakat untuk mematuhinya.

Berdasarkan hasil temuan penelitian, menunjukkan bahwa 96, $67 \%$ responden menyatakan Pemerintah Daerah Bungo perlu melakukan kajian dan studi kelayakan mengenai transportasi publik. Dapat kita pahami bahwa Kebijakan publik pada hakekatnya adalah intervensi pemerintah yang betujuan untuk mengubah kondisi yang ada atau mempengaruhi arah dan kecepatan dari perubahan yang sedang berlangsung dalam masyarakat.
Intervensi itu dilakukan melalui suatu serangkaian strategi kebijakan dengan menggunakan berbagai peralatan/instrumen kebijakan. Dalam hal ini yang sangat diperlukan adalah pengambilan kebijakan berdasarkan kategori, yakni terlebih dahulu mengajukan rancangan kebijakan umum, seperti dengan mengacu kepada bentuk undang-undang atau Keputusan Presiden dan sebagainya. Sementara dalam suatu propinsi, selain dari peraturan dan kebijakan yang diambil pada tingkat pusat juga ada Keputusan Gubernur atau Peraturan Daerah yang diputuskan oleh DPRD. Bila daerah seperti Kabupaten Bungo melaksanakan kebijakan umum, maka perlu memperhatikan :

1) Cakupan kebijakan yang meliputi keseluruhan wawasan; hal ini berarti harus melibatkan beragam stake holders dalam perumusan kebijakan umum tersebut,

2) Tidak berjangka pendek, masa berlakunya atau tujuan yang ingin dicapai dengan kebijakan tersebut berada dalam jangka panjang ataupun tidak mempunyai batas waktu tertentu.

3) Strategi kebijakan umum tidak bersifat operasional; dalam hal ini, Pemerintah Daerah mencetuskan orientasi kebijakan yang bersifat umum dan komprehensif mengatur dari segala segi 
untuk mempersiapkan suatu sistem yang bisa dijalankan kapan saja, meskipun terjadi pergantian kepemimpinan.

c. Ketertarikan Responden Pada Sarana Transportasi Publik di Muara Bungo.

Temuan penelitian menunjukkan bahwa, kebanyakan jumlah responden tertarik mencoba dengan jumlah 91,67\% sedangkan yang tidak tertarik mencoba hanya 8,33\% karena berbagai alasan. Animo masyarakat yang tinggi direpresentasikan oleh 275 orang responden yang tertarik mencoba, apabila Pemerintah Daerah Bungo membuka layanan transportasi publik, adalah modal berharga bagi upaya berkelanjutan dalam memajukan daerah di sektor transportasi.

Bentuk preferensi (pilihan) moda transportasi publik Moda masyarakat Muara Bungo

Dari temuan penelitian menunjukkan pilihan responden jenis kendaraan yang cocok untuk transportasi publik adalah Bis Menengah sebesar $43 \%$, sedangkan jumlah terendah yaitu $10,67 \%$ memilih jenis kereta wisata (city train). Pada sisi fasilitas dalam kendaraan, yang sangat diperlukan menurut opini responden adalah petugas keamanan, yang dipilih sebesar $37,33 \%$, sedangkan jumlah terendah adalah $1,33 \%$ yang menjawab kapasitas daya angkut besar yang sangat diperlukan dari Sarana Transportasi Publik.

Adapun penyelenggaraan layanan transportasi harus berdasarkan pada prinsipprinsip berikut:
a. Aman;
b. Nyaman;
c. Mudah;
d. Ekonomis;
e. Lancar; dan
f. Ramah Lingkungan.

\section{KESIMPULAN DAN SARAN}

Berdasarkan hasil penelitian dan pembahasan di atas, maka dapat ditarik suatu kesimpulan yaitu, perlunya kajian transportasi publik di Muara Bungo, hasil temuan penelitian, menunjukkan bahwa responden menyatakan Pemerintah Daerah Bungo perlu melakukan kajian dan studi kelayakan mengenai transportasi publik. Selanjutnya bahwa tingkat keinginan masyarakat sangat tinggi terhadap ketersediaan sarana transportasi publik di Muara Bungo, kebanyakan jumlah responden tertarik mencoba bila telah ada sarana transportasi publik di Muara Bungo. Pada sisi lain responden menginginkan subsidi pemerintah daerah sebagai dukungan utama sistem transportasi publik. Masyarkat tertarik mencoba transportasi publik untuk menghindari kemacetan lalu lintas. Bentuk preferensi (pilihan) moda transportasi publik 
Moda masyarakat Muara Bungo menunjukkan pilihan responden jenis kendaraan yang cocok untuk transportasi publik dengan pilihan tertinggi adalah Bis Menengah. Adapun penyelenggaraan layanan transportasi publik perlu memperhatikan prinsip: Aman, Mudah, Ekonomis, Lancar dan Ramah Lingkungan.

Saran dari peneliti, bagi Pemerintah Daerah Kabupaten Bungo, melalui Leading Sector Dinas Perhubungan, bersama-sama instansi terkait perlu melakukan studi kelayakan bagi pelaksanaan sistem transportasi publik, mengacu pada temuan penelitian yang menunjukkan animo responden sebagai representasi masyarakat yang tinggi pada sarana transportasi publik.

\section{REFERENSI}

Abidin, Said Zainal. 2006. Kebijakan Publik. Jakarta: Suara Bebas.

Agustino, Leo. 2008. Dasar-dasar Kebijakan Publik. Bandung: Alfabeta.

Halim, DK. 2008. Psikologi Lingkungan Perkotaan. Jakarta: Bumi Aksara.
Imawan, Prasetya. 2007. Penelitian Kualitatif dan Kuantitatif untuk Ilmu Sosial, FISIP UI, Jakarta.

Koentjaraningrat. 2009. Pengantar Ilmu Antropologi. Jakarta: Rineka Cipta.

Muthfisari, Alnurrizki. 2007. Sopan Santun Berlalu Lintas. Klaten: PT Maraga Borneo Tarigas.

Morissan. 2012. Metode Penelitian survey. Jakarta: Kencana.

Sadyohutomo, Mulyono. 2008. Manajemen Kota dan Wilayah. Jakarta: Bumi Aksara.

Santoso, Purwo. 2005. Menata Sistem Transportasi; mendekatkan demokrasi dengan rakyat dalam jurnal wacana, Tahun VI. Yogyakarta.

Sugiyono. 2010. Metode Penelitian Administrasi dilengkapi dengan Metode $R \& D$. Bandung: Alfabeta.

Thoha, Miftah. 2010. Birokrasi Politik Indonesia. Jakarta: PT Raja Grafindo Persada.

Wismulyani, Endar. 2008. Transportasi di Indonesia dari Masa ke Masa. Klaten: Cempaka Putih.

Widodo. T. 2008. Metode Penelitian Kuantitatif. Surakarta: LPP UNS dan UNS Press. 